\title{
Çeuresel söylemler ve Gelişmekte Olan Ülkeler
}

Yrd. Doç. Dr. Aslı Erbil

Ístanbul Teknik Üniversitesi, Fen ve Edebiyat Fakültesi, Insan ve Toplum Bilimleri Bölümü
Günümüzde Türkiye gibi "gelişmekte olan ekonomiler" sınıfında sayılan ülkelerde çevre ve çevre sorunlarının çözümü dendiğinde akla ilk gelen, ortaya çıkan sorunların fen bilimlerinin (doğa bilimleri, mühendislikler, tıp) çevreyi ele alış biçimi ve sunduğu çözüm önerileri gelmektedir. Ancak sosyal bilimler alanında çalışan akademisyenler, çevre ve çevre sorunlarını daha geniş bir çerçevede ele almaktadırlar. Sözgelimi, (John Dryzek, The Politics of the Earth 1997) adlı kitabında, çevre ve çevre sorunlarının tanım olarak ekosistemlerin ve insan sosyal sistemlerinin kesişiminde yer aldığını belirtir. Aynı paralelde Ulrich Beck (1992) ise çevre problemlerinin çerçevesini şöyle çizer:

"Çevre problemleri fiziki çevremizin problemleri değil-köken ve sonuçları itibariyle-insanların tarihleri, yaşam koşullarl, dünya ve gerçekle olan bağlantıları, sosyal-kültürel ve politik durumları ile ilişkili olarak ortaya çıkan tamamen sosyal problemlerdir."

Çevre ile ilgili sorunların ele alınışında hâkim olan düşünce tarzı, fen bilimleri çerçevesinde geliştirilen çözümlere öncelik verir ve sorunların ortaya çıkışının asıl nedeni olan sosyal düşünce ve sistemi, çözümün bir parçası olarak görmez. Halbuki Beck ve Dryzek'in alıntılarından da anlaşıldığı üzere, çevre sorunlarına olan cevaplar sadece ekoloji, mühendislik gibi fen bilimleri disiplinlerinde değil, sosyal bilimlerin de yer aldığ sistemlerin kesişiminde bulunabilir. Ve hatta çevre politikası konusunda çalışma yapan sosyal bilimciler ve çevre bilimciler arasında giderek yaygınlaşan bir düşünceye göre de, sosyal bilimler fen bilimleri temelli çözümlerin çerçevelenmesinde yol gösterici rol üstlenmelidir. Bu amaçla özellikle 1990'lı y1llardan sonra sosyal bilimler disiplinlerinden çeşitli araştırmacılar çevre kavramının politik ve sosyal boyutunu daha detaylı olarak incelemeye başlamışlar ve günümüzde çevre olgusunu anlamak için çevresel söylemlerin incelenmesini yararlı bir yöntem olarak sunmuşlardır. Ancak bu çevresel söylemlerle ilgili araştırma, çalışma ve sinıflamalar sadece bu söylemlerin ortaya çıktığı endüstriyel gelişimini tamamlamış
Çevre ile ilgili sorunların ele alınışında hakim olan düşünce, fen bilimleri çerçevesinde geliştirilen çözümlere öncelik verir, sorunların ortaya çıkışının asıl nedeni olan sosyal düşünce ve sistemi çözümün bir parçası olarak görmez. Ancak çevre sorunlarına olan cevaplar sadece fen bilimleri disiplinlerinde değil, sosyal bilimlerin de yer aldığ kesişiminde bulunabilir. Bu anlayış özellikle Türkiye gibi "gelişmekte olan ekonomiler" sınıfında sayılan ülkelerde daha da ağırlık kazanmaktadır. Bu makalenin amacı, ağırlıklı olarak çevre ve sorunlarının kent planlama gibi uygulama kolu olan disiplinler açısından nasıl ele alınması gerektiğini saptamak, aslında çevre kavramının fen bilimleri boyutundan çok sosyal bir boyuta sahip olduğunu ortaya koymaktır. İkinci olarak, özelde ülkemizde genelde gelişmekte olan ülkelerde çevrenin sosyal boyutunun nasıl algılandığını tartışmaya açmaktır. Bunun için ilk önce sosyal bilimlerde çevre kavramı çevresel söylemler ele alınarak açıklanmaya çalışılacak, daha sonra çevre olgusu ve çevresel söylemlerin değerlendirilmesi gelişmekte olan ülkeler bağlamında yapılarak söz konusu

ülkelerde çevre kavramının algılanışı çerçevelenecektir.

Summary:

The overriding view seeks solutions for environmental problems mostly in the positive sciences (natural sciences, engineering), not in the social processes that, indeed, the main cause of the problems. This understanding dominates especially in the 'emerging economy' countries, such as Turkey. However, the real solutions for environmental problems can be

found at the intersection of positive science and social science disciplines. The main goal of the article is determine how environment and its problems should be deal with in the disciplines, as city planning, that also have practice, and scrutinize that environment concept has social science dimension as much as positive science dimension. Secondly, to open up discussion how environment concept is perceived in the developing countries. To reach the goals, first, I will examine environmental discourses in order to understand the environment concept in social sciences, than I will elaborate the dimensions and the meaning of the environment concept for the developing countries through environmental discourses.

Anahtar Kelimeler:

Çevre, Çevresel söylemler, Gelişmekte olan ülkeler Keywords:

Environment, Environmental discourses, Developing countries 
kapitalist toplumları içermekte ve tartışmalar ağırlıklı olarak bu ülkelerin gündemi ile sınırlı kalmaktadır.

Endüstriyel ülkeler içinde tartışılan söz konusu söylemlerin gelişmekte olan ülkeler açısından boyutları ise henüz yeterli ölçüde ele alınıp değerlendirilmemiştir. Günümüzde küresel boyutları da olan çevre sorunlarının ve ilintili kavramların sosyo-politik yönden tartış1masında gündemin sadece 'gelişmiş' batı toplumlarının gündemi ile sınırlı kalması ise gelişmekte olan ülkeler kategorisinde sayılan ülkeler için tehlike oluşturmaktadır. Uluslararası anlaşmalar, yaptırımlar, kredi veren uluslararası sivil toplum örgütlerinin ortaya koyduğu şartlar nedeni şu veya bu şekilde söz konusu anlayışlar (genelde söylemler-özelde politikalar) gelişmekte olan ülkelerin gündemine ithal edilmektedir. Bu durum çevre sorunlarını çözmeye yönelik stratejilerin, Türkiye gibi gelişmekte olan sınıfında sayılan ülkelerde, ana fikri bilinmeden uygulamaya konulması sonucunu doğurmaktadır. Başarısız, benimsenmemiş veya yetersiz sonuçlar getiren bu pratiklerin amacina ulaşılamaması ise genelde ülkenin geliş(me)mişlik seviyesine bağlanmaktadır. Tabii burada 'uyarlama' pratiğinin kendi içinde geniş bir tartışma gerektirdiğini ve uyarlama sürecinde sosyal, kültürel, politik etkenlerin ekonomik ve teknolojik olanaklardan daha çok önem taşıdığını vurgulamak gerekir. Ancak uluslararası anlaşmalar ve öne sürülen şartlar çerçevesinde uyarlama süreci düşünülmeden 'ithal' edilen anlayışlar ve stratejiler uyarlama süreci atlanarak uygulamaya konulmaya çalışılmakta, bu bağlamda ortaya çıkan sonuçlar daha da sakıncalı bir tablo sergilemektedir.

Bu makalenin amacı, ağırlıklı olarak çevre ve sorunlarının kent planlama gibi uygulama kolu olan disiplinler açısından nasıl ele alınması gerektiğini saptamak için çevre kavramının fen bilimleri boyutu kadar sosyal bir boyuta da sahip olduğunu ortaya koymaktır. İkinci olarak, Türkiye'nin de dâhil edildiği gelişmekte olan ülkelerde, çevrenin sosyal boyutunun nasıl algılandığını tartışmaya açmaktır. Sözkonusu amaca ulaşmak için ilk önce sosyal bilimlerde çevre kavramı, çevresel söylemler tartışılması yoluyla açıklanmaya çalışılacak, detaylı olarak çevresel söylemler ve sinıflamalar konusunda bilgi verilecektir. Daha sonra çevre olgusu ve çevresel söylemlerin değerlendirilmesi gelişmekte olan ülkeler bağlamında yapılarak, söz konusu ülkelerde çevre kavramının algılanışı çerçevelenecektir.

\section{Söylem kavramından çevresel söylemlere}

Her ne kadar teknik ve bilimsel platformlarda açık olarak söylenip, incelenmese de, pratik yaşamda sosyal düşünce, çevre problemlerinin tanımlanıp çözümlenmesinde esasları belirlemektedir. $\mathrm{Bu}$ görüş 1şığında, dünyadaki çevre politikaları ile ilgili söylemleri incelediğimizde, genellikle 'teknik' olarak görülen çevre sorunlarına yönelik tanım ve çözümlerin sosyal düşünce sistemlerini yansitan söylemlerde belirlendiğini gözlemlemek çok da zor değildir. Burada söylem kavramını çevresel söylem bağlamında biraz açmak istiyorum. Türk Dil Kurumu Sözlüğgü’ne göre “ifade veya kalıplaşmış söz” olarak tanımlanan söylem, Hastings tarafından dünyayı anlamak ve algılamak için kullanılan kavram ve kategoriler olarak açıklanmıştır (1999:10). John Dryzek ise söylemi "Dünyayı algılamada paylaşılan bir yol" olarak tanımlanmış ve konuşulan dilde gizlenen/temellenen söylemin benimseyenlerin bilgileri algilama ve 
yorumlamalarına yardımcı olduğunu belirtmiştir. Bu nedenle her söylem analiz, tartışma, anlaşma ve anlaşmazlıkları algılarken, kendi içinde önyargılar, yargı ve içerikleri de barındırır (Dryzek, 1997). Micheal Foucault'nun çalışmalarında sık sık kullanarak sosyal bilimler dünyasına önemini vurguladığı söylem kavramı aslında, post-yapılanma/post-modernizm dönemi ile tartışılmaya başlanan parçacı anlayışın-sistemin bütününün incelenmesinde ve anlaşılmasında esas çerçeveyi oluşturur (Hastings, 1999).

Hollandalı çevre politikacı Maarten Hajer'e gore ise söylem günlük konuşma dilinde 'tartışma' veya 'konuşma modu' olarak tanımlanabilir. Ancak sosyal bilimler çerçevesinde bu tanımın tekrar gözden geçirilmesi gerektiğini de belirten Hajer, söylemi bir dizi pratikler yolu ile zaman ve mekan içinde üretilip, yeniden şekillendirilip ve dönüştürülerek fiziksel-sosyal gerçeklere anlam veren düşünce, kavram ve sınıflamaların spesifik bileşimi olarak tanımlamaktadır (Hajer, 1995: 44).

Buna bağlı olarak Hajer (1995), zaman ve mekan spesifik olan 'Çevre Söylemi’nin, geçmiş deneyimlerimizi ve mevcut kabullerimizi yansıtan doğa modeline göre kontrol edilip-yönlendirildiğini belirtmektedir. Doğal çevrenin durumuna ilişkin herhangi bir anlayış temsillere dayanmakta ve her zaman parçacı pratiklerin bileşimiyle oluşan sosyal seçimleri yansıtmaktadır. Bu açıklama çevreyi dışarıda/orada gören anlayışın tamamen terk edildiği anlamını da vermektedir. Dolayısıyla, 'gerçek' anlayışımızı oluşturan parçacı pratikleri tam olarak kavramadan çevre politikası veya planlaması gibi alanlardaki dinamiklerin özünü anlamak da mümkün değildir.
Dünya literatüründe, Hajer gibi çevresel söylemler konusunda açıklama yapan ve tartışan birçok araştırmacı bulunmaktadır. Bunlardan Necdet Teymur'un yazarlığını yaptı̆̆g ve 1982 yılında yayınlanan Çevresel Söylem (Environmental Discourse) adlı kitabında çevre söylemi, söylem analizi metodu yardımı ile mercek altına alınmış ve çevre söylemini etkileyen faktörler parçacı sosyal, tarihsel ve kurumsal olaylarla ilişkilendirilerek ortaya konmuştur. Benzer olarak, Eric Darier'in editörlügüüü yaptığ 1 ve sekiz sosyal bilimcinin katkıda bulunduğu Çevrenin Söylemleri (Discourses of the Environment, 1999) adlı yapitta Micheal Foucault'nun bilinçli olmayarak etkilediği çevreci kritiğini ele alan bölümler bulunmakta ve söz konusu yazılar çerçevesinde çevreye dair söylemler sosyal bilimlerin geniş perspektifi altında ele alınmaktadır (Örneğin: çevre bilincinin ortaya çıkışı, ekolojik modernizasyon ve çevresel risk gibi başlıklar çerçevesinde). 2003 yılında Yvonne Rydin'in araştırmalarının sonucunu ortaya koyan yapitta ise (Conflict, Consensus, and Rationality in Environmental Planning: An Institutional Discourse Approach) doğrudan planlama disiplinine referans verilmekte, kurumsal yapılar incelenirken hava kirliliği kontrol ve yönetimine, konut alanları politikasına ilişkin konular detaylı olarak ele alınmaktadır.

Daha önce de vurgulandığ gibi, bu yazının amacı çevreye ilişkin söylemlerin sistematik olarak incelenmesi ve sunulmasından çok, ağırlıklı olarak çevre ve sorunlarının kent planlama gibi uygulama kolu olan disiplinler açısından nasıl ele alınması gerektiğini saptamak için çevre kavramının fen bilimleri boyutu kadar sosyal bir boyuta da sahip olduğunu 
ortaya koymaktır. Söz konusu ele alış içinde, çevresel söylemler araçsal olarak kullanılmakta ve tartışmaya açılmaktadır. Çevresel söylemler kendi başına bir inceleme konusu olması ve bu konuya ilişkin geniş bir çerçevede araştırma ve yazılar bulunmasına rağmen belirtilen amaç kapsamında çevresel söylemleri sosyo-politik olarak ele alan ve açıklayan görüşlere yer verilecektir. Bu bağlamda, çevre söylemlerini endüstriyel ve gelişmekte olan ülkeler çerçevesinde tartışmaya açmadan önce dünya literatüründe çevreye ilişkin söylemler, iki sosyal bilimcinin sınıflandırmaları özetlenerek yapılacaktır. Söz konusu sınıflamalara geçmeden önce açıklanması gerekli iki nokta bulunmaktadır. Birincisi, çevresel söylemlerin doğa bilimlerinde veya mühendislik dallarında olduğu gibi tek bir doğru ve sonucu olan önermeler içermeme özelliğine sahip oluşudur. $\mathrm{Bu}$ nedenle makalede özellikle iki ayrı sosyal bilimcinin görüşleri detaylı olarak verilmiştir. Benzer tip açılımların zaman-mekân ve kişiye bağlı olarak çok çeşitli yapılabileceği muhakkaktır.

Ancak burada sunulan söylem kategorileri, okuyucuya uygulama ve teoride genel geçer olabilecek bilgileri de ulaştırdığından Dryzek ve Harvey'in söylem sınıflamaları önem taşımaktadır. İkincisi, bugünkü anlamı ile çevre bilinci kavramı, ilk önce gelişmiş ülkelerde oluşmuştur. Bu nedenle çevreye yönelik pratikler ve bu pratikleri çerçeveleyen politikalar ve dolayısıyla çevresel söylemler de bu ülkelerde ortaya çıkmıştır. Söz konusu söylemler 'batı merkezli' söylemlerdir, ancak günümüzde küreselleşme gibi çeşitli etmenlerle tüm dünyada çeşitli biçimlerde görülebilmektedir.

\section{Çevresel söylemlerin sınıflandırılması} Coğrafyacı David Harvey, Adalet, Doğa ve Farklılığın Coğrafyası (Justice, Nature and the Geography of Difference, 1996) adlı kitabının bir kısmını, Avusturalyalı siyaset bilimci John S. Dryzek ise, Yeryüzünün Politikası: Çevresel Söylemler (The Politics of the Earth: Environmental Discourses, 1997) adl1 kitabının tamamını yirminci yüzyıl sonlarında baskın olan çevresel söylemlere ayırmıştır. Harvey, çevresel söylemleri dört ana başlık altında açıklamaktadır:

\section{1. Çevresel Yönetimin 'Standart Görüşü'}

$\mathrm{Bu}$ görüş çerçevesinde çevresel problemler, ortaya çıktıktan sona ele alınması gereken konulardır. Ve bu strateji çevre ile ilgili hiç bir konunun 'gelişmenin' (yani sermaye birikiminin) önüne geçmemesi inancını benimser. Ancak, eğer gerekli olursa, çevresel kirlenmeler, kirlenme olayı gerçekleştikten sonra etkin bir biçimde temizlenebilir. $\mathrm{Bu}$ görüsste, çevre problemleri hatalardan kaynaklanan kazalar olarak algılanır ve mekan-olay spesifik sorunların çözüm yolları büyük çoğunlukla problemin ortaya çıkmasından sonra ele alınır. Endüstri ise, çevre ile ilgili maliyetleri 'dışsal' olarak görür (Harvey, 1997: 373-376).

\section{Ekolojik Modernizasyon}

Ekolojik modernizasyon, ekonomik aktivitelerin sistematik olarak çevreye zarar verdiği görüşü üzerine kurulur, ve bu nedenle toplumun ekolojik ve hukuksal düzenlemeye dayanan önleyici tedbirler alması gerektiğini savunur. Bürokratik çözümler yerini sistematik politika geliştirmeye, kurumsal düzenlemelere ve düzenleyici pratiklere bırakır; çevre maliyeti endüstri tarafından içselleştirilir. Harvey, bu formülasyonda anahtar 
kelimenin 'sürdürebilirlik' kavramı olduğunu vurgular (Harvey, 1997: 377-383).

\section{3. Özel Mülkiyetin Bilgece Kullanımı}

Ekolojik modernizasyon ve bunun getirdiği koruyucu anlayış, özellikle hammadde çıkaran ve doğal kaynakları kullanan mülk sahipleri/yatırımcılar tarafından çekingenlikle karşılanmış ve korumacı tavra karşı 'bilgece kullanım' hakkını savunan bir hareket başlatılmıştır. Bu savunuya göre, doğal kaynakların korunması kolektif anlayış-mülkiyet içinde zordur ve hatta bazı durumlarda mümkün değildir. Özel mülkiyet himayesinde gerçekleşecek koruma daha etkin ve akılcıdır. Çünkü mülk sahibi ve yatırımcı zaten bindiği dalı kesmeyecek ve kazancının, dolayısı ile hayatının devamını sağlayabilmek için gerekli olan ekolojik korumayı kişisel bilinci ile maksimize edecektir. Kökleri A.B.D. Başkanı Thomas Jefferson dönemine (1801-1809) uzanan bu 'Ortodoks' çevreci anlayış, özellikle A.B.D'nin batı eyaletlerinde Federal Hükümet'in özel mülkiyeti düzenlemesine karşı duran bir grubun görüşünü temsil etmektedir

(Harvey, 1997: 383-385).

\section{4. Çevresel Eșitlik ve Dar Gelirlinin} Savunusu

Yine A.B.D. kaynaklı olan Çevresel Eşitlik hareketi çevre sorunlarının oluşumu ve çevrenin temizlenmesinde sınıf, ırk farkı gözetilmesini protesto ederek yüksek gelirli- beyaz ırk sınıfına sağlanan olanakların diğer kesimlere de sağlanması gerektiğini savunur. Özellikle maddi ve politik gücü olmayan toplum kesimlerinin yaşam alanlarına 'benim arka bahçemde değil' (Not-in-My Backyard) anlayışı ile aktarılan çevre kirliliklerinin (çöp alanları, toksin alanlar, asbestosdan inşa edilmiş evler gibi) temizlenmesi ve 'hiç kimsenin arka bahçesinde değil' (Not-in-Anybody's Backyard) görüşünün benimsenmesi gerekliliğini ortaya koyar (Harvey, 1997: 385-391).

Avusturyalı siyaset bilimci John Dryzek ise Harvey'in ortaya koyduğu söylemleri bir başka biçimde ve daha detaylandırarak sınıflamıştır. Bu sınıflama içinde söylemler dört ana başlık altında incelenmiştir (Resim 1).

\begin{tabular}{|l|l|c|}
\hline & Reformist & Radikal \\
\hline Normal/Sıradan & Problem Çözücü & Yaşamın Devamlılı̆̆ 1 \\
\hline Hayalci & Sürdürülebilirlik & Yeşil Radikalizm \\
\hline
\end{tabular}

Sıradan söylemler mevcut politik ve ekonomik sistemi veri olarak kabul ederek toplum yapısını değiştirmeyi gerektirmeyen etkinlikleri öngörür. Buna karşın hayalci söylemler mevcut sistemi yeniden tanımlamak, değiştirmek isteği içindedir ve çevre problemlerini engel değil firsatlar olarak görür.

Reformist söylemler sadece sistem içinde reformlar getirirken radikal söylemler ise kökten değişiklikler önerirler (Dryzek, 1997: 14).

\section{Yașamın Devamlılı̆̆}

John Dryzek'in siradan ve radikal olarak sınıfladığ 1 bu söylem ilk olarak 1970 başlarında Roma Kulübü tarafından ortaya konmuştur. İnsanlığın tarımsal ve endüstriyel aktivitelerini destekleyen doğal kaynaklar ve ekosistemlerin stokları süregelen ekonomik büyüme ve nüfus artışı nedeniyle bir gün tükenecektir savını ortaya atan Roma Kulübü, 1972’de 
düşüncelerini büyük yankı getiren ve dört milyon satan Büyümenin Sınırları (The Limits to Growth, Meadows vd., 1972) adli kitapta yayımlamıştır. Bu söyleme göre, küresel felaketi önlemede çare, yönetici, bilim adamları ve sorumlu elitlerin getireceği, mevcut sistemlerdeki kontrolün artırılmasına yönelik köktenci çözümlerde bulunabilir. Taşıma kapasitesi, ekonomik modelleme gibi kavramlar bu söylem çerçevesinde ortaya çıkmıştır. Ancak Özgürlükçüler/Özgürlükçü Söylemi bahsedilen sınırların varlığını reddetmiş ve insan medeniyetinin ve ürettiği teknolojinin, çevre problemleri de dahil, çözmeye yeteneği olduğunu savunmuştur (Dryzek, 1997:21-60).

\section{2. Çevre Problemlerini Çözmek}

Sıradan ve reformist olarak sınıflandırılan bu yaklaşım mevcut politika-ekonomik verileri kabul eder ve çevre problemlerinin çözümü için ağırlıklı olarak kamu politikalarını içeren düzeltmeler yapılması gerektiğini savunur. Düzenlemeler, liberal demokratik yönetimlerin pragmatik problem çözme kapasitelerine bağlıdır. Bu söylem çerçevesinde çözüme ulaşmak için kitleler üç değişik yolla koordine edilebilir: Bürokrasi, demokrasi ve piyasa. Birinci yolda, Yönetimsel

Rasyonalizasyon koordinasyon sağlar. $\mathrm{Bu}$ söyleme göre sosyal problemin çözümü uzmanlara bırakılmıştır. Yönetimsel rasyonalizasyon, vatandaş, üretici ve tüketiciyi dışlayarak, bilimsel ve teknik uzmanlığg bürokratik hiyerarşi içinde kullanmayı hedefler. İkinci söylem olan, Demokratik Pragmatizm çevre problemlerinin çözümünün merkezi yönetimle sağlanamayacağını, çözümün ancak birçok görüşün ortaya konabildiği ve halkın katılımının sağlandı̆̆ süreçle mümkün olduğunu savunur. Ekonomik Rasyonalizasyon söylemi ise piyasa mekanizmalarının halkın yararı için problemleri çözeceğini söyler (Dryzek, 1997:61-119).

\section{Sürdürülebilirlik}

Hayalci ve reformist bir kimlik taşıyan ve 1980’lerde popülerlik kazanan 'sürdürülebilirlik' kavramı, geçen yirmi beş yıl içinde kesin olarak tanımlamasa da uluslararası platformda benimsenen bir söylem olmuştur. Bu düşüncede çevre problemlerinin, ekonomik ve ekolojik değerler arasındaki sorun ve karşıtlıklar giderilerek çözüleceği, ayrıca olagelenin aksine insan ve doğal sistemlerin uyum içinde olabileceği fikirleri yatmaktadır. Ekonomik büyüme desteklenmeli ancak çevreye zararsız ve sosyal eşitliği sağlayacak biçimde yönlendirilmeli savunusu söylemin bir parçasıdır ancak bu savunu, ağırlığı ekonomik ve ekolojik dengenin bulunabileceği tartışmalarına bırakmış, çevresel eşitlik ayrı bir söylem olarak ortaya çıkmıştır. Sürdürülebilirlik kategorisinde sayılan bir başka söylem ise Ekolojik Modernizasyon'dur.

Sürdürülebilirlik söylemine paralel olarak görülen ekolojik modernizasyon söylemi kapitalist ekonominin yeniden yapılanarak çevrenin daha çok koruyucu bir platforma çekilebileceğini savunur. Çevrenin tahribini yapısal bir problem olarak görür; yeşil endüstri gibi kavramların ortaya konması ve çevreyi kirletmeyen teknolojilerin geliştirilmesi yolu ile mevcut politikaları değiştirmeyi hedefler. Burada çevrenin maliyeti içselleştirilir ve yeni bir üretim biçimi öngörülür

(Dryzek, 1997:120-152). 


\section{Yeşil Radikalizm}

Hayalci ve radikal olarak sinıflanan bu söylem, mevcut endüstri toplumunun yapısını ve çevrenin ele alınış biçiminin değişmesi gerektiğini savunurken insanlık, toplum ve bunların dünyadaki yerleri konusunda sıra dışı görüşler sergiler. Derin radikalizmi ve hayal gücü göz önüne alındığında bu söylem içinde birçok açılımın olması şaşırtıcı değildir. Bu geniş açılımı iki ana başlık altında toplamak mümkündür. Yeşil Romantizm, aydınlanmanın önerdiği rasyonel ve gelişmeci zihniyeti reddeder. Mevcut dünya sistemini tümden değiştirme ve dünyayı koruma arayışı içinde artistik ve estetik değerleri temel alan bir yaşam, politika ve manipüle edilmemiş doğal bir dünya hayal eder. Ancak bunu yapmak için dünyaya egemen olan ekonomik ve politik sistemin değişsinimi değil, bireylerin değişimini esas alır. Daha çok insanın 'yeni ekolojik hassasiyet deneyimini’ yaşayarak dünyayı değiştireceğini düşünür. Bu düşünüş ve istek dışında bir önermesi veya hedefi yoktur. Yeşil Rasyonalizm ise mevcut sosyal, ekonomik ve politik yapının problemleri çözebileceğini kabul ederken gerekirse kurumsal yeniden yapılanmaya gidilebileceğini öngörür. Bu söyleme göre ekolojik krize çözüm, politik etkinlik ve yapısal değişimle sağlanabilir

(Dryzek, 1997: 153-193).

İki araştırmacının çalışmaları çerçevesinde sunulan çevresel söylemler, daha önce de belirtildiği gibi aslında burada kısaca özetlenenlerden farklı biçimlerde sınıflandırılabilir. Bu tür farklı sınıflamaların yapılabileceğini vurgulamanın yanı sıra dikkat çekilmesi gereken bir başka nokta daha bulunmaktadır: gerçek yaşamda veya pratikte yukarıda sınıflanan söylemler çoğunlukla hibritler olarak bulunmaktadır. Burada teorik olarak ortaya konan biçimleriyle 'saf' olarak da bulunabilen söz konusu söylemler gerçek yaşamda genellikle melezlenmiş olarak uygulanmaktadır.

Sosyal bilimciler tarafından teorik olarak ortaya konan bu anlayışlar (söylemler) insanların-toplumların çevre ile ilintili pratiklerini yönlendiren kabullerdir. Bilinçli veya bilinçsiz olarak uygulansın, bu kabuller çevre sorunlarını önleme ve çözmeye yönelik fen bilimleri (mühendislik ve doğa bilimleri) pratiklerini çerçeveler. Daha önce de değinildiği gibi Ulrich Beck gibi sosyal bilimciler, sosyal ve kültürel yönü olmayan açıklamaların dar görüşlü olduğunu vurgular. Çevresel kirleticiler ve bunların dağılımının açıklaması genellikle 'doğa' bilimleri tarafından yapılmakta ve söz konusu bilimler de insan varlığını 'organik bir materyal' olarak kabul etmektedir. Doğanın bir parçası olarak kabul edilen insan varlığının yarattığı sorunlar ise yine aynı varlığın icat ettiği teknolojik ilerlemeler sayesinde çözülmeye çalışılmaktadır. Çevre ve doğa ile ilgili tartışmalar 'insansız' olarak, 'teknokratik ve naturalistik' bağlamda yapılmaktadır (Beck, 1992:24). Bu sosyal düşünceden yoksun, çözümü doğa, teknoloji, ekonomi, tıp dallarında arayan tutumlar genel olarak gelişmiş toplumların tutumları olarak işaret edilmektedir (Beck, 1992:25). Çevre bilincinin ilk önce yeşerdiğ i gelişmiş ülkelerin gündeminde bile çevre sorunlarını Beck'in de ifade ettiği dar anlamda tartışmak aslında sorunları görmemezlikten gelmek veya geçiştirmeye 


\footnotetext{
$I_{\text {Insanlik Gelişim Endeksine }}$ göre gelisme derecesi 0.800 ve üzerinde olan ülkeler

$\boldsymbol{2}_{\text {Insanlik Gelişim Endeksine }}$ göre geliş̧me derecesi 0.500-0.799 arasinda olan ülkeler

3 Insanlık Gelişim Endeksine göre gelişme derecesi 0.500 altında olan ülkeler

çalışmaktan kaynaklanmaktadır. Bu dar anlayışı genişletmeye çalışan Harvey, Dryzek, Hajer ve diğer sosyal bilimciler çabalarını ortaya koymaktadırlar. Ancak asıl sorun olan nokta söz konusu tartışmaların, daha önce de belirtildiği gibi, genellikle endüstriyel gelişimini tamamlamış kapitalist toplumları içermesi ve ağırlıklı olarak bu ülkelerin gündemi ile sınırlı kalmasıdır.
}

\section{Gelişmekte olan ülkelerde çevre kavramı ve çevresel söylemler}

Gelişmekte olan ülkeler bağlamında çevresel söylem ve çevre kavramını tartışmaya açmadan önce gelişmiş ve gelişmekte olan ülke sınıflandırılmasının nasıl yapıldı ̆̆ına ve Ulrich Beck'in Risk Toplumu (Risk Society) teorisine kisaca değinmek istiyorum. Dünya'da yer alan ülkeler, özellikle koloni döneminin son buluğu ve Amerika Birleşik Devletleri'nin İkinci Dünya Savaşı sonrası politik ve ekonomik olarak güçlü olarak çıktığg 1950'li yıllardan sonra, çeşitli biçimlerde sınıflandırılmışlardır. Birinci Dünya-İkinci Dünya-Üçüncü Dünya, Gelişmiş-Az gelişmiş, Endüstrileşmiş-Endüstrileşen, Gelişmiş-Gelişmekte terimleri söz konusu sınıflandırmalar için kullanılagelmektedir. $\mathrm{Bu}$ makalenin konusu bağlamında çevre olgusunun göreceli olarak daha çok önem taşıdığı ve çevre ile ilgili söylemlerin yeşerdiği, tartışıldığı ülkeler ile bu ülkeler dışında kalanları ayrı kategorilerde ele almak gerekliliği doğmuştur. Bu gereklilik çerçevesinde sınıflama gelişmiş (endüstrisini tamamlamış olarak sayılan batı toplumları) ve gelişmekte olan ülkeler olarak kabul edilmiştir. Sınıflamada Birleşmiş Milletler Örgütünün her y1l güncelleyerek yayımladığ 1 , ülkelerin ekonomik, sosyal, kültürel, politik durumlarını birçok ölçüte göre değerlendiren İnsanlık Gelişim Endeksi temel alınmış ve yüksek gelir grubunda sayilan ve toplumun yaygin kesimlerine iyi yaşam çevresi ve koşulları sunan ülkeler gelişmiş $\left.{ }^{(}\right)$, (endüstrisini tamamlamış) orta $^{(2)}$ ve düşük(3) gelir $^{(2)}$ grubunda sayılan ülkeler ise gelişmekte olan ülkeler olarak kabul edilmiştir. İnsanlık Gelişim Endeksi sadece ekonomik verilere göre oluşturulmadığ değerlendirmede eğitim, kadının iş ve sosyal yaşama katılımı, kültürel donatılar, çevre standartları, seçme ve seçilme yaşı, halkın karar alma süreçlerine katılma oranları gibi yaşamın her kesimini kapsayan ölçütler de göz önüne alındığından bu sınıflama daha rasyonel bulunmuştur. Asıl tartışmaya geçmeden değinilmesi gereken bir başka nokta ise Ulrich Beck'in Risk Toplumu (Risk Society) teorisidir. Risk Toplumu adlı kitabında Beck, bittiği düşünülen modernizasyon sürecinin henüz tamamlanmadığını, bu dönemin başlangıcında ortaya çıkan refahın (veya Beck'in deyimiyle 'iyilerin') dağıtım sürecinin şimdi yerini refahın yan ürünü olarak ortaya çıkan kirliliklerin (Beck'in deyimiyle 'kötülerin') dağıtım sürecine bıraktığını, yani bir "Risk Toplumu”nun ortaya çıktığını öne sürmektedir .

Aydınlanma sonrası başlayan endüstrileşme ve modernizasyon süreci ile doğal kaynaklar yoğun olarak kullanılıp özellikle şimdiki endüstrileşmiş ülkelerin sahip olduğu gelir düzeyinin elde edilmesi sağlanmıştır. Modernizm sonrası veya post-modernizm olarak adlandirılan dönemde ise bu yoğun kullanım sonucu ortaya çıkan çevre sorunlarından dem vurulmaya başlanmıştır. Bu gelir ve sorunların (kar ve zararların) eşit dağılımı problemi ise günümüz toplumlarını 
yakından ilgilendiren bir konu olarak ortaya çıkmakta, az temsil edilen güçsüz kesimlerin (kadın ve çocukların, gelişmekte olan ülkelerin) sadece zararları değil, karı da paylaşması gerektiği fikri ortaya atılmaktadır( ${ }^{(4)}$ (Beck, 1992). Beck'in bahsettiği karların (refahın, gelirlerin) dağıtımı son derece yavaș ve sınırlı olurken, risklerin (çevre kirliliklerinin) dağıtımı, bir toplumun çeşitli katmanları arasında veya küreselleşen dünyada toplumlar arasında büyük bir hızla devam etmektedir.

Söz konusu risklerin hızlı dağıtım sürecinde, tıpkı refahın dağılımının kısıtlı kalması gibi, biraz önce tartışılan söylemler de dünyanın kısıtlı bir kesiminde tartışılmaktadır. Örneğin, Beck'in mantığından yola çıkan Hajer (1995) özellikle 1980 sonrası Batı toplumları olarak adlandırılan gelişmiş ülkelerde yeşeren 'Ekolojik

Modernizasyon' söyleminden bahsetmiş ve söz konusu kötü yan ürünlerin kaynağı olan endüstrinin çevresel kirlilikleri içselleştirilmesi yolu ile yok etme, ekonomi-ekoloji arasında dengelerin kurulması yolunda çaba harcandığını anlatmış, ancak bu söylemde genellikle zaman ve mekân belirtilmemiş ve dünyanın her yanında mevcut durum (endüstriyel gelişimini tamamlamış ülkelerdeki) durumla aynı kabul edilmiştir. Gelişmekte olan ülkelerin durumları tartışma konusu edilmemiştir. Bu durum söylemlerin çoğu için geçerlidir, bir önemsemezlik denemese de bir batı-merkezlilik çevre söylemlerinin çerçevelenmesinde ve tartışılmasında genelde görülmektedir.

Bu konudaki en büyük istisnayı 'Ekolojik Modernizasyon' söylemi ile kardeş sayılan ve aynı dönemlerde popülerlik kazanan
'Sürdürebilirlik' söylemi gösterir. Bu söylemin ortaya çıkışından (1970'ler) bu yana, özellikle 1992 Birleşmiş Milletler Rio Zirvesi'nden sonra, gelişmiş ve gelişmekte olan ülkeler çevre konusundaki görüşlerini sürdürülebilirlik söylemi çerçevesinde yoğun olarak ortaya koymaya başlamışlardır. Gelişmiş ülkeler 'çevre'yi gelişmekte olan ülkelerin gündemlerine bir nevi zorla sokmuşlardır. Fakat gelişmekte olan ülkeler, endüstriyel ülkelerin önerdiği önlemler paketini ancak ve ancak bunun maliyetinin gelişmiş ülkeler tarafından ödenirse kabul edeceklerini, onlar için henüz çevre korumanın ekonomik gelişmeden daha önemli olmadığını, üstelik gelişmiş ülkelerin endüstriyel faaliyetlerinden kaynaklanan ve küreselleşen çevre sorunlarının (ozon tabakasındaki delik gibi) yükünün gelişmekte olan ülkelerin omuzlarına yüklenmesinin büyük haksızlık olduğunu vurgulamışlardır. Bütün bu karşı çıkışlara rağmen geliş̧mekte olan ülkelerde çevre kavramı 'sürdürülebilirlik' söylemi bağlamında popüler bir konu olarak tartışılmaya başlanmıştır.

Arturo Escobar gibi bazı sosyal bilimciler ise gelişmekte olan ülkelerde çevre konusunun ele alınışının ve alınış biçimlerinin gelişme söylemiyle ilintili olduğunu belirtir. 'Modern' toplum yaratmada araç olarak kullanılan 'gelişme' söyleminin, dünya toplum ve insanlarını belli kontrol koordinatlarında tutmada kullanıldı $\breve{g} ı n ı$ ve panoptik bakışın ${ }^{(5)}$ sosyal kontrol araçlarının eşanlamlısı olarak karşımıza çıktı̆̆ııı vurgular (Escobar, 1995).

Escobar'a göre, gelişmeci zihniyet doğa kavramını çevre kavramına indirgerken veya eşanlamlı olarak kullanırken, savunusunun hareket noktasin belirler.

5 Panoptik Bakış: Kuledeki gardiyanın, kendisi görünmeden gözlediği bakıs 
yayımlanan Ortak Geleceğimiz (WCED) adlı raporla dünyaya tanıtılmış ve küresel 'ekorakrasi' devri başlatılmıştır. Burada dikkat çekilmesi gereken asıl nokta, özellikle çevrenin yönetilebilir olduğunu vurgulayan bu anlayışın küresel bir çevre koruma için çeşitli stratejiler üretmekte olduğu ancak söz konusu stratejilerin sadece büyüme ve gelişme modellerinin devamı olduğudur. Bu stratejilerin Bruntland Raporunda 'Biz' diye tüm dünya halklarını ve insanlarını işaret eden kesim tarafından değil de, bu raporu da yazan, dünyayı yöneten güçler tarafından tüm dünya için geliştirildiği, herkes hemfikirmiş veya hemfikir olmak zorundaymış gibi bir ortam yaratılarak sunulduğu vurgulanır (Escobar, 1995). Gelişmeci zihniyet, fakir ülkelerin planlama yolu ile şu veya bu şekilde gelişme patikasında ilerleyeceğini varsayar, bu nedenle de planlama ve yönetimin 'rasyonel' ve 'objektif' oluşu gelişim için vazgeçilmezdir. Söz konusu çevresel yönetim çerçevesinde dünyanın en ücra köşesinde yaşayan insanlar, kendi yerelliklerinden koparılarak dünya 'kaynaklarından' biri olarak görülmeye zorlanmaktadır. Escobar'a göre, her geçen gün gelişmekte olan ülkelerin dünya güçlerine olan bağımlılıkları artarken, sürdürülebilir gelişme dilini kullanmak oldukça zordur. Çünkü sürdürülebilir gelişme anlayışının ideali olan,kalkınmaya çalışan ülkelerin endüstrileşme sürecini atlayıp enformasyon ve bioteknolojiye temellenen endüstri sonrası bir toplum yaratma düşüncesi çalışamaz bir fikirdir (Escobar, 1995).

Tüm bu tartışmalar içinde Alman çevre siyasetçisi Wolfgang Sachs'in 1999'da belirttiği gibi 'çevre' ve 'gelişme'kampları arasında bir çekişme başlamıştır. Gelişmiş ülkeler, çevreye olan hakları vurgularken gelişmekte olan ülkeler çevresel eşitlikten söz etmekte ve gelişmiş ülkelerin küresel çevre sorunları yaratma pahasına kullandıkları gelişme haklarının kendilerinde hala saklı olduğunu belirtmektedirler.

Bu bağlamda, gelişmekte olan ülkelerin çevrenin önemi ve anlamı konusunda gelişmiş ülkelerle aynı paralelde düşünmediğini söylemek çok da zor değildir. Bunun nedenlerini Redclift ve Goodman (1991) şöyle açıklamaktadır: "Kentleşmiş, endüstriyel toplumlarda göreceli olarak az bir kesimin yaşam kaynakları çevre koruma etkinlikleri ile tehdit edilmektedir. Endüstriyel kapitalizmin göreceli olarak genis bir kitleye (fakat hepsine değil) yüksek yașam standardı să̆laması nedeniyle ortaya çıkan 'yaşam kalitesi' gibi kavramlar politik önceliklerin belirlenmesinde önemli rol oynamaktadır" (4)... "Buna karşın, gelişmekte olan ülkelerde öncelik temel yaşam için şart olan barinma-beslenme gibi gereksinimlere verilmekte ve çevresel politikalara karşı bir cephe açılmaktadır" (Redclift 1984: 47).

Buna bağlı olarak çevresel yönetim-sürdürebilirlik gibi söylemlerde çerçevelenen ve uluslararası gelişme örgütlerince (Birleşmiş Milletler, Dünya Bankası, OECD gibi) desteklenen çevre koruma stratejileri gelişmekte olan ülkelerde gelişmiş ülkelerdeki başarıyı yakalayamamaktadır. Ek olarak, gelişmekte olan ülkelerin kısa dönemli ekonomik kazanç için ekonomik değerlerin yaratılması ve kaynakların elde edilmesi yolunda çevrenin kalitesinin bozulma riskini göze alırken (Goodman ve Redclift 1991: 5), gelişmiş ülkelerin çevresel kaliteyi ekonomik gelişmeye tercih 
etmeleri (Desai, 1998; Goodman ve Redclift, 1991) şaşırtıcı değildir.

Ancak gelişmiş ülkelerin kendi gündemlerini gelişmekte olan ülkelere dayatma çabaları süregelmektedir.

Örneğin 1992 Birleşmiş Milletler Rio Zirvesi'nde kabul edilen "Gündem 21" eylem planının neredeyse tüm dünya ülkelerinde uygulanmaya konulması ile sürdürülebilirlik söylem ve kavramı, en azından slogan olarak-birçok ülkenin resmi çevre, söylemi durumuna gelmiştir.

Rio Zirvesinden 10 yil sonra yapılan 2002 Birleşmiş Milletler Zirvesi de küreselleşen-daha doğrusu küreselleştirilen-sürdürülebilirlik kavramının kabulünü zirvenin adına yansitarak bir kez daha vurgulamıştır: Birleşmiş Milletler Sürdürülebilir

Gelişme Dünya Zirvesi. Güney Afrika’nın Johannesburg kentinde gerçekleşen bu zirvede, 1992 Rio Zirvesi'nde alınan kararların ne kadar uygulanabildiği, o günden bugüne kat edilen yolun mercek altına alınması ana temalardan birini oluşturmuş, Gündem 21 eylem planı yine önemli bir konu olarak zirvede yer almıştır. Gündemin amaçları ve sonuçları ayrı bir tartışma konusudur ancak burada vurgulanması gerekli nokta, söz konusu zirve gibi uluslararası nitelikteki organizasyonların Türkiye gibi gelişmekte olan ülkelere ne gibi izler bıraktığının tartışılması gerekliliğidir. Örneğin 'Sürdürülebilir Gelişme' (Sustainable Development) olarak tercümesi yapılan kavramın neden dilimizde 'Sürdürülebilir Kalkınma’ olarak yer ettiği (Pusch, 1999), neden Johannesburg Zirvesi için ön hazırlık yapan grubun adının 'Ulusal Çevre ve Kalkınma Programı’ olduğu bir soru işaretidir. Daha önce de değinildiği gibi, Türkiye gibi gelişmekte olan ülkeler bu tür konuları detaylı olarak tartışmamaktadır. Türkiye'de çevrenin hukuksal boyutu, doğa bilimleri boyutu göreceli olarak daha fazla ele alınırken, sosyo-politik boyutu sadece eleştirel anlamda ve kısıtlı çerçevede kalmaktadır. Böyle bir ortamda da çevresel söylemlerin neden gelişmekte olan ülkelerde gelişmiş ülkelerdeki kadar tartışılmadığı açıktır.

Ancak bu demek değildir ki tartışılması gereksiz ve yararsızdır. Söz konusu toplumlar, çevre kavramı, çevre koruması ve planlaması konusunda nerede durduğunu daha açık bir şekilde ortaya koymalı, kendi gerçekleri içinde dünyadaki söylemleri ve kendi söylemlerini yorumlamalıdır. Aksi halde küreselleşen dünyada dışsal zorlama ve dayatmalarla söz konusu söylemlerin yarattığ politika ve stratejiler uluslararası örgütler veya anlaşmalar yolu ile gelişmekte olan ülkelerde uygulanmaya konacak, gündemine yerleştirilecektir. İthal edilerek uygulanan bu stratejilerin etkisi veya dar anlamda başarısı ise büyük olasılıkla tartışılacaktır 
KAYNAKC A

Beck, U. 1992. Risk Society: Towards a New Modernity, Sage Publications, London.

Darier, E. 1999. Discourses of the Environment. Blackwell Publishers, Oxford, UK; Malden, MA.

Desai, U. 1998. Ecological Policy and Politics in Developing Countries : Economic Growth, Democracy, and Environment, SUNY series in international environmental policy and theory, State University of New York Press. Albany.

Dryzek, J. 1997. The Politics of the Earth: Environmental Discourses, Oxford University Press, Oxford.

Escobar, A. 1995. Encountring Development: The Making and Unmaking of the Third World, Princeton University Press, Princeton.

Goodman, D, ve Redclift M. R. 1991. Environment and development in Latin America : the politics of sustainability, Issues in environmental politics, Manchester University Press, Manchester; New York

Hajer, M. A. 1995. The Politics of Environmental Discourse: Ecological Modernization and the Policy Process. Oxford University Press, Oxford

Harvey, D. 1996. Justice, Nature and the Geography of Difference. Blackwell Publishers, Oxford

Hastings, A. 1999. Discourse and Urban Change: Introduction to the Special Issue, Urban Studies, 36 (1), 7-12.

Lash vd. 1996. Risk, Environment and Modernity: Towards a New Ecology, Sage Publications, London. Meadows, vd. 1972.

Pusch, B. 1999. The Ecology Debate Among Muslim Intellectuals in Turkey, Islam en Turquie: Les Annales de l'Autre Islam, 6:195-209.

Redclift, M. 1984. Development and Environmental Crisis: Red or Green Alternatives. Methuen, London; New York.

Redclift, M. ve Goodman, D. 1991. Introduction Goodman, D. ve Redclift M. R ed., Environment and Development in Latin America, Manchester University Press, Manchester.

Rydin, Y. 2003. Conflict, Consensus and Rationality in Environmental Planning: An Institutional Discourse Approach. Oxford University Press, Oxford; New York

Sachs, W. 1999. Planet Dialectics : Explorations in Environment and Development, Zed Books, London; New York.

Teymur, N. 1982. Environmental Discourse: A Critical Analysis of Environmentalism in Architecture, Planning, Design, Ecology, Social Sciences and the Media. Question Press, London.

WCED (World Commission on Environment and Development), 1987. Our common future. Oxford University Press, Oxford ; New York. 